University of Vermont

UVM ScholarWorks

Rubenstein School of Environment and Natural Rubenstein School of Environment and Natural Resources Faculty Publications

$12-1-2011$

\title{
Underestimating the costs of conservation in Southeast Asia
}

\author{
David P. Edwards \\ Princeton School of Public and International Affairs \\ Brendan Fisher \\ Princeton School of Public and International Affairs \\ Xingli Giam \\ Princeton University \\ David S. Wilcove \\ Princeton School of Public and International Affairs
}

Follow this and additional works at: https://scholarworks.uvm.edu/rsfac

Part of the Climate Commons, Community Health Commons, Human Ecology Commons, Nature and Society Relations Commons, Place and Environment Commons, and the Sustainability Commons

\section{Recommended Citation}

Edwards DP, Fisher B, Giam X, Wilcove DS. Underestimating the costs of conservation in Southeast Asia. Frontiers in Ecology and the Environment. 2011 Dec;9(10):544-5.

This Letter to the Editor is brought to you for free and open access by the Rubenstein School of Environment and Natural Resources at UVM ScholarWorks. It has been accepted for inclusion in Rubenstein School of Environment and Natural Resources Faculty Publications by an authorized administrator of UVM ScholarWorks. For more information, please contact scholarworks@uvm.edu. 
Indonesia: Bogor Agriculture University.

MoF (Ministry of Forestry of Indonesia). 2010. Statistik Kehutanan BP2HP Tahun 2009. Balai pemantauan pemanfaatan hutan produksi wilayah XIII Samarinda. Jakarta, Indonesia: Ministry of Forestry.

Pinard MA and Putz FE. 1996. Retaining forest biomass by reducing logging damage. Biotropica 28: 278-95.

Putz FE, Blate GM, Redford KH, et al. 2001. Biodiversity conservation in the context of tropical forest management. Conserv Biol 15: 7-20.

Putz FE, Zuidema PA, Pinard MA, et al. 2008. Tropical forest management for carbon retention. PLoS Biol 6: 1368-69.

Venter O, Meijaard E, Possingham $\mathrm{H}$, et al. 2009. Carbon payments as a safeguard for threatened tropical mammals. Conserv Lett 2: 123-29.

doi:10.1890/11.WB.030

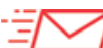

\section{Underestimating the costs of conservation in Southeast Asia}

In their letter, Ruslandi et al. raise some interesting points but also make several misleading statements, which overall make us confident that the cost of protecting the primary rainforests of Southeast Asia is indeed very high.

Ruslandi et al. promote the use of carbon payments to enhance carbon stocks, fund reduced-impact logging, and improve forest management, arguing that such payments could prevent highly destructive logging practices and forest conversion - an analysis that they suggest was lacking from Fisher et al. (2011a). However, the explicit aim of our paper was to evaluate the use of REDD+ to protect the remaining primary (ie unlogged) forests of Southeast Asia. Although we agree with Ruslandi et al. that carbon payments have important roles to play in the protection of degraded forests (eg Edwards et al. 2010, 2011), by definition, payments for reduced-impact logging cannot provide any protection for primary forests.

We welcome the publication of Tropical Forest Foundation timber records and extraction costs in the Ruslandi et al. letter; these new data clearly show that, in their study area, logging is more costly, timber yields are smaller, and profits are lower than those in Sabah, Borneo, where we worked. Ruslandi et al. take these data, plus timber yields from seven other studies, and compare them with our yields. However, the authors overlook many other relevant studies. Here, we conduct a more exhaustive review of extraction data from 25 study locations (including those in Ruslandi et al.) across Southeast Asia. Extraction rates are highly variable, ranging from $25 \mathrm{~m}^{3}$ in Sarawak, Borneo, to $205 \mathrm{~m}^{3}$ in the Philippines ( mean \pm standard error $[\mathrm{SE}]=84.9$ \pm 9.0; WebTable 1). All studies present yields from operations with 50-60-cm diameter at breast height (dbh) cutting limits, but there is additional timber value beneath this limit - consisting of both the most valuable and different (eg Octomeles spp, Neolamarckia spp, and Duabanga spp) tree species - that must also be offset. In Fisher et al. (2011a), this value (representing logging trees of between 40 - and $60-\mathrm{cm}$ dbh as well as the growth before the second cut, discounted at $10 \%$ over a 16 -year span between cuts) was roughly $\$ 1000$ per hectare, a value missed in Ruslandi et al. (but explored in Fisher et al. 2011c); note: all monetary values in this letter, unless noted otherwise, are expressed in 2009 US dollars.

For each timber harvest listed in WebTable 1 - combined with price and extraction costs for harvests in Malaysia (Fisher et al. 2011a), Indonesia (Ruslandi et al.), and elsewhere (taken as the midpoint of the two studies) - we find that profits from logging operations in tropical Southeast Asia could fall in the range of $\$ 1260$ to $\$ 13840$ per hectare $($ mean $\pm \mathrm{SE}=\$ 5563 \pm 757$; WebTable 1). But again, this estimate disregards the values below $50-60-\mathrm{cm}$ dbh. Ruslandi et al.'s estimate of $\$ 2268$ is thus much less than half the regional average timber value.

We appreciate the use of the average standardized oil-palm yield curve by Ruslandi et al., which they use to derive a net present value (NPV) of $\$ 6766$ per hectare of oil palm (versus
$\$ 11240$ in our paper). But - importantly - the NPV of agricultural yield rents is heavily determined by (1) the discount rate used and (2) the price of the crop. In WebTable 2, we vary these two factors to calculate the NPVs for a non-optimized oil-palm plantation using the same yield curves as those in Ruslandi et al., and we show a huge range of potential values.

Two things are evident. First, lower discount rates (toward 5\%) shift the \$6766 estimate upward; since the Malaysian bond market rate is $4-10 \%$, these higher values seem more reasonable. Second, since we conducted our analysis, the price per metric ton of crude palm oil increased from $\$ 788$ to $\$ 1048$ (22 Jul 2011; www.palmoilhq.com/crudepalm-oil-cpo-futures/), which has a large positive impact on profits. Combining July's price with $5 \%$ and $10 \%$ discount rates suggests that oilpalm profits are as high or higher than those presented in our paper (WebTable 2).

High estimates for oil-palm profits are supported by the financial reports of large plantation companies. Industrial Oxygen Incorporated's (IOI's) 2010 Annual Report gives an operating profit per hectare of mature oil palm of Malaysian Ringgit (RM) 8148 (= \$2400; 2009 exchange rate where US $\$ 1=$ RM 3.39) (p28 in IOI 2010) per year, which equates to an NPV of $\$ 15800(r=10 \%$, production years 4-25). Wilmar International's 2009 Annual Report calculates the NPV of one hectare of oil palm as ranging from $\$ 9250$ to $\$ 20710$ (Wilmar's accounting discount rate ranges from $7.36 \%$ to $15.9 \%$; Wilmar International 2009). While the NPV used by Fisher et al. (2011a) - \$11 240 - falls within the range of values reported by Wilmar International and below IOI's valuation, Ruslandi et al.'s NPV of $\$ 6766$ and Venter et al.'s (2009) NPV of $\$ 5510$ largely underestimate profits from oil-palm production, as reported by major palm producers themselves.

Ruslandi et al. also incorrectly use Fisher et al.'s (2011a) Equation 4 to calculate a breakeven price for car- 
bon based on their estimates. In our paper, the carbon emitted from logging was explicitly tied to the magnitude of timber removed (and hence the value of the timber). Ruslandi et al. remove only a fraction of the timber, at higher cost, and therefore reap a much lower potential rent. They then divide this rent by the total amount of carbon that would be liberated if they were logging $152 \mathrm{~m}^{3} \mathrm{ha}^{-1}$ and then converting to oil palm. Surely the carbon emissions from a Ruslandi et al. forest of $54 \mathrm{~m}^{3} \mathrm{ha}^{-1}$ cannot liberate the same levels of carbon as the primary forests analyzed in Fisher et al. (2011a), but in using our equation, they take a small profit and divide it by a huge carbon emissions profile, greatly (and erroneously) driving down the breakeven price to just $\$ 18$ per metric ton of $\mathrm{CO}_{2}$.

For the reasons discussed above, we are confident that the breakeven price for carbon remains much higher than Ruslandi et al.'s estimate. The key question is whether lower breakeven prices than the $\$ 44-46$ per metric ton of $\mathrm{CO}_{2}$ in our paper can compete on a global carbon market. In Brazil, $90 \%$ of deforestation might be thwarted by carbon prices of $\$ 2.80$ per metric ton $\mathrm{C}(\sim \$ 10$ per metric ton $\mathrm{CO}_{2}$; Nepstad et al. 2007), while in East Africa, a carbon payment of $\$ 6.50$ per metric ton $\mathrm{CO}_{2}$ has the potential to stop deforestation (Fisher et al. 2011b). Both of these studies indicate that carbon can be stored much more cheaply in tropical regions other than Southeast Asia. The reasons for this disparity are simple: Southeast Asia is a nexus of high timber yield, high timber prices across tree species, and high-value agriculture. Fisher et al. (2011a) and this further analysis thus suggest that intrinsic, cultural, and social values, rather than carbon payments, are most likely to protect Southeast Asia's remaining primary lowland forests. We caution against underestimating the costs of protecting Southeast Asian versus other primary forests, lest conservation planning rely too heavily on unrealistic outcomes.

David P Edwards ${ }^{1 * \dagger}$, Brendan

Fisher ${ }^{1}$, Xingli Giam ${ }^{2}$, and

David S Wilcove ${ }^{1,2}$

${ }^{1}$ Woodrow Wilson School of Public and International Affairs, Princeton University, Princeton, NJ; ${ }^{\dagger}$ current address: School of Marine and Tropical Biology, James Cook University,

Cairns, Australia

*(dave.edwards@jcu.edu.au);

${ }^{2}$ Department of Ecology and

Evolutionary Biology, Princeton

University, Princeton, NJ
Edwards DP, Fisher BF, and Boyd E. 2010. Protecting degraded rainforests: enhancement of forest carbon stocks under REDD+. Conserv Lett 3: 313-16.

Edwards DP, Larsen TH, Docherty TDS, et al. 2011. Degraded lands worth protecting: the biological importance of Southeast Asia's repeatedly logged forests. P R Soc B 278: 82-90.

Fisher B, Edwards DP, Giam X, and Wilcove DS. 2011a. The high costs of conserving Southeast Asia's lowland rainforests. Front Ecol Environ 9: 329-34.

Fisher B, Lewis SL, Burgess ND, et al. 2011b. Replacing deforestation with agricultural yield gains, and fuel efficiency via carbon payments in subSaharan Africa. Nat Clim Change 1: 161-64.

Fisher B, Edwards DP, Larsen TH, et al 2011c. Cost-effective conservation: calculating biodiversity and logging tradeoffs in Southeast Asia. Conserv Lett; doi:10.1111/j.1755-263X.2011.00198.x.

IOI (Industrial Oxygen Incorporated). 2010. Proven balance - 2010 annual report. Putrajaya, Malaysia: IOI Corporation.

Nepstad D, Soares-Filho B, Merry F, et al. 2007. The costs and benefits of reducing carbon emissions from deforestation and forest degradation in the Brazilian Amazon. Falmouth, MA: Woods Hole Research Center.

Venter O, Meijaard E, Possingham $\mathrm{H}$, et al. 2009. Carbon payments as a safeguard for threatened tropical mammals. Conserv Lett 2: 123-29.

Wilmar International. 2009. Wilmar in China - 2009 annual report. Singapore: Wilmar International Limited.

doi:10.1890/11.WB.031

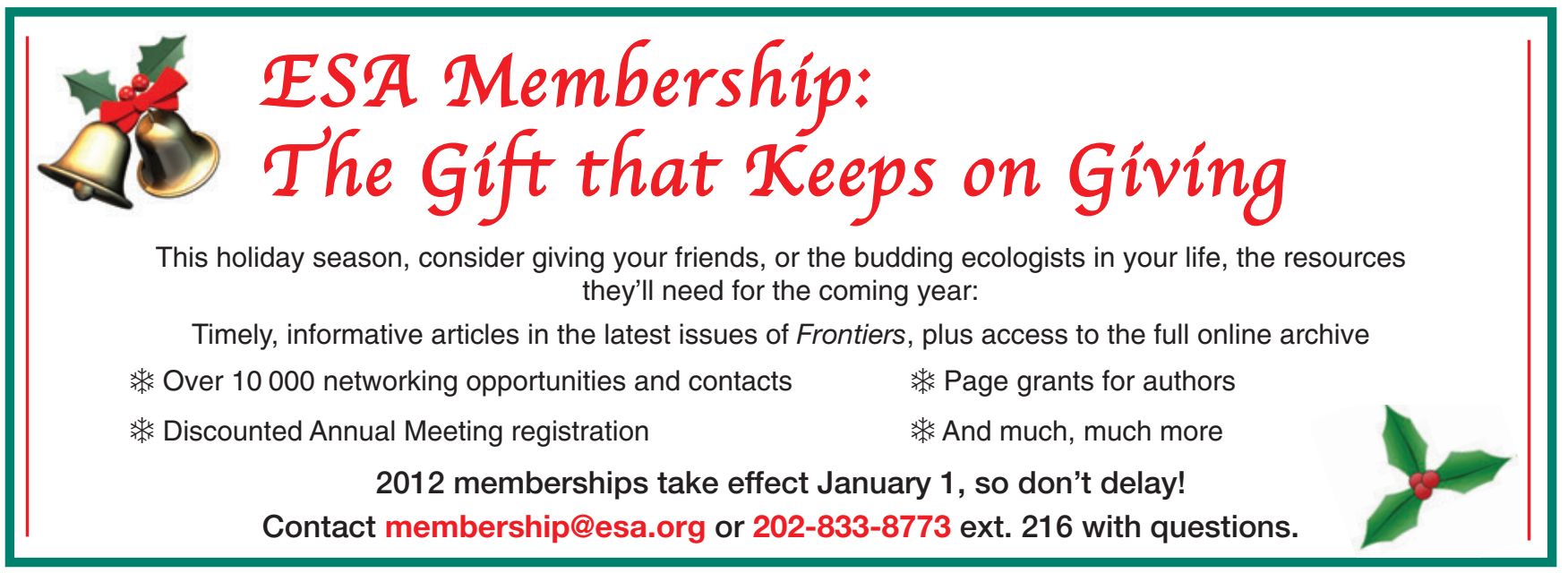

